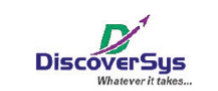

Published by DiscoverSys

\section{Better knowledge associated with better hand hygiene compliance among nurses in Pembina Kesejahteraan Umat (PKU) Muhammadiyah Hospital, Gamping, Yogyakarta, Indonesia}

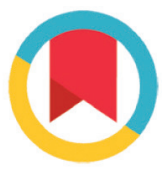

CrossMark

\author{
Liena Sofiana, ${ }^{1 *}$ Gunadi Ardana, ${ }^{1}$ Suci Musvita Ayu ${ }^{1}$
}

\begin{abstract}
Background and purpose: Nosocomial infections can cause a significant number of deaths every day worldwide. Failure to perform good and proper hand hygiene is considered a major cause of infections related to health care. Health workers who are the most vulnerable in transmitting infections are nurses, because they are accompanying patients for 24 hours. This study aims to explore the relationship between knowledge, attitudes and motivation with the level of nurses' compliance in hand hygiene practices in Class III inpatient wards of Pembina Kesejahteraan Umat (PKU) Muhammadiyah Hospital, Gamping, Yogyakarta.

Methods: This was a cross-sectional observational analytic study. The study involved all 41 nurses working in Class III inpatient wards at PKU Muhammadiyah Gamping Hospital. The instruments for

was analysed with statistical software comprised of univariate and bivariate analysis with Chi-square test and Fisher's Exact test.

Results: The results indicate the prevalence of nurses' hand hygiene compliance was $70.7 \%$. Factor that significantly associated with hand hygiene compliance was knowledge $(p=0.001)$, while attitudes $(p=0.577)$ and motivation $(p=0.771)$ were not correlated significantly.

Conclusion: Good knowledge increases the hand hygiene behavior among nurses in Class III inpatient wards of PKU Muhammadiyah Gamping Hospital. It is necessary to improve awareness through providing training on nurse compliance with the prevention and control of nosocomial infections, especially regarding proper steps and timing of hand hygiene practices.
\end{abstract} data collection was a questionnaire and an observation sheet. Data
${ }^{1}$ Faculty of Public Health, Ahmad Dahlan University, Yogyakarta

\section{*Correspondence to:}

Liena Sofiana ; Faculty of Public Health, Ahmad Dahlan University, Yogyakarta;

liena.sofiana@ikm.uad.ac.id

Keywords: Nurse compliance, hand hygiene, knowledge, nosocomial infection

Cite this Article: Sofiana, L., Ardana, G., Ayu, S.M. 2020. Better knowledge associated with better hand hygiene compliance among nurses in Pembina Kesejahteraan Umat (PKU) Muhammadiyah Hospital, Gamping, Yogyakarta, Indonesia. Public Health and Preventive Medicine Archive 8(1): 72-76. D0I: 10.15562/phpma.v8i1.237

\section{INTRODUCTION}

Infectious diseases are still the main cause of morbidity and mortality rates in the world. Infectious diseases can occur in health care setting known as healthcare associated infections (HAIs). HAIs also referred to as nosocomial infections, which are infections occur in patients during the process of care in a hospital or other health care facilities. Nosocomial infection causes 1.4 million deaths every day worldwide. ${ }^{1}$ It is currently one of the causes of increasing morbidity and mortality in hospitals, which become an emerging health problem in both developing and developed countries. $^{2}$

The Indonesian government has issued an infection prevention and control policy in hospitals and other health facilities. The policy was stated in the Regulation of the Indonesia Ministry of Health Number 27 Year 2017 regarding Guidelines for Infection Prevention and Control in Health Care Facilities. ${ }^{3}$ The policy is an attempt to break the cycle of disease transmission and to protect patients, health workers, visitors and the public who receive services both in hospitals and other health services. ${ }^{3}$

One important measure to reduce nosocomial infections is hand hygiene practices. Failure to perform good and proper hand hygiene is considered as a major cause of infections related to health services and the spread of multi-resistant microorganisms in health facilities and has been recognized as an important contributor to the diseases' outbreak. ${ }^{4}$ As a result of non-compliance with hand hygiene in hospitals, $9 \%$ of nosocomial infections worldwide occur with variations between 3\%-20\% during hospitalization. ${ }^{5}$ Health workers who are most vulnerable in transmitting infections are nurses, because they are accompanying patients for 24 hours. Improved hand hygiene among nurses was suggested to have a significant role in contributing to the prevention of nosocomial infections. Awareness about hand hygiene in health workers is a fundamental aspects to prevent 
infection in hospitals. ${ }^{6-8}$

Seeing the high incidence of nosocomial infections that occur both in the world and also in Indonesia, it is necessary to reduce the number of incidents, namely by applying hand hygiene. ${ }^{9}$ Hand hygiene is an important basic technique in preventing infection and the most cost-effective way to prevent nosocomial infections in the hospital environment. Awareness on the importance of hand hygiene in health workers is necessary in the efforts to prevent nosocomial infections. Several studies indicated that knowledge of hand hygiene is the most basic skills that must be acquired by a nurse. ${ }^{6-8,10}$ Meanwhile, attitude and motivation are also related to nurse compliance with the application of hand hygiene. ${ }^{6}$

At PKU Muhammadyah Gamping Hospital, nosocomial infections occurred more frequently in the Class III inpatient rooms. Based on observations and interviews with an infection prevention and control superintendent at PKU Muhammadiyah Gamping Hospital, nurses have known about the five moments of hand hygiene and the six steps of hand hygiene procedure according to World Health Organization (WHO) standards and can practice it well, but there are some nurses who did not properly implement the practices, including nurses at the Class III inpatient rooms. This study aims to explore association between knowledge, attitude and motivation to hand hygiene compliance among nurses working at Class III in-patient rooms of PKU Muhammadiyah Gamping Hospital.

Table 1. Socio-demographic characteristics of respondents

\begin{tabular}{lcc}
\hline Respondents' characteristics & $\mathbf{n}$ & \% \\
\hline Age (year) & 7 & 17.1 \\
$21-30$ & 33 & 80.5 \\
$31-40$ & 1 & 2.4 \\
$41-50$ & & \\
Gender & 9 & 22.0 \\
Male & 32 & 78.0 \\
Female & & \\
Education & 16 & 39.1 \\
Diploma (D3) & 6 & 14.6 \\
Bachelor (S1) & 19 & 46.3 \\
Ners (Nurse profession) & & \\
Working period & 24 & 58.5 \\
$\quad \leq 3$ years & 17 & 41.5 \\
$>3$ years & & \\
Basic infection control training & 5 & 12.2 \\
Never & 36 & $\mathbf{1 0 0 . 0}$ \\
Ever & $\mathbf{4 1}$ & \\
\hline Total & & \\
& &
\end{tabular}

\section{METHODS}

This was a cross-sectional quantitative study. The population of this study was permanent nurses working in Class III inpatient rooms of $\mathrm{PKU}$ Muhammadiyah Gamping Hospital, amounting to 41 people. All nurses in the study population were selected as the samples.

Tools and instruments used in this study were questionnaires and observation sheets. Variables which were collected including knowledge on hand hygiene, attitude and motivation toward hand hygiene practices. During the observation, we observed five moments of hand hygiene and steps on performing hand hygiene practices, including the moments before contact with patients and before performing aseptic.

Data collection was carried out by the researchers, the process of data collection started from direct observation to nurses when washing hands before measuring the independent variables with a questionnaire. This was done so the nurses do not know that observations are being made by researchers. Data was analysed using statistical software including descriptive and bivariate analysis using Chi-Square test and Fisher's Exact test. This study has received an ethical approval from the Ethics Committee of Ahmad Dahlan University with registration number 011908081 issued on September 27, 2019.

\section{RESULTS}

Respondents' characteristics based on age, gender, level of education, working period and basic infection prevention training are presented in Table 1.

Table 1 shows that most of the nurses were 31 40 years old $(80.5 \%)$ and female $(78.0 \%)$. Based on education level, most respondents have done a nurse profession education (Ners) (46.3\%), while more than half $(58.5 \%)$ have worked for three years or less and most of them (87.8\%) had ever attended basic infection control training held at PKU Muhammadiyah Gamping Hospital.

Table 2 shows that $46.3 \%$ of the nurses have low level of knowledge on proper hand hygiene practices. Most of the nurses (73.2\%) have poor attitude toward hand hygiene practices and 34.1\% of them have low motivation to perform proper hand hygiene practices. There were 12 nurses (29.3\%) who did not comply with proper hand hygiene practices.

Table 3 shows that the majority (57.9\%) of nurses who have low level of knowledge did not comply with the hand hygiene practices, whilst only $4.5 \%$ of those who have high level of knowledge did 
Table 2. Knowledge, attitude, motivation and compliance with hand hygiene practices of nurses in Class III inpatient rooms of PKU Muhammadiyah Gamping Hospital in 2019

\begin{tabular}{lcc}
\hline Variables & $\mathbf{n}$ & \% \\
\hline Knowledge & & \\
$\quad$ Low & 19 & 46.3 \\
High & 22 & 53.6 \\
Attitude & & \\
$\quad$ Poor & 30 & 73.2 \\
$\quad$ Good & 11 & 26.8 \\
Motivation & & \\
Low & 14 & 34.1 \\
$\quad$ High & 27 & 65.9 \\
Compliance with hand hygiene & & \\
No & 12 & 29.3 \\
$\quad$ Yes & 29 & 70.7 \\
\hline
\end{tabular}

Table 3. Relationship between knowledge, attitude, motivation and compliance with hand hygiene practices among respondents

\begin{tabular}{|c|c|c|c|c|c|c|c|c|}
\hline \multirow{3}{*}{ Variable } & \multicolumn{4}{|c|}{ Compliance } & \multirow{2}{*}{\multicolumn{2}{|c|}{ Total }} & \multirow{3}{*}{$\begin{array}{c}\text { PR } \\
(95 \% \mathrm{Cl})\end{array}$} & \multirow{3}{*}{$\mathbf{p}$} \\
\hline & \multicolumn{2}{|c|}{ Not-comply } & \multicolumn{2}{|c|}{ Comply } & & & & \\
\hline & $f$ & $\%$ & $f$ & $\%$ & $f$ & $\%$ & & \\
\hline \multicolumn{9}{|l|}{ Knowledge } \\
\hline Low & 11 & 57.9 & 8 & 42.1 & 19 & 100.0 & \multirow{2}{*}{$\begin{array}{c}12.7 \\
(1.8-89.8)\end{array}$} & \\
\hline High & 1 & 4.5 & 21 & 95.5 & 22 & 100.0 & & 0.001 \\
\hline \multicolumn{9}{|l|}{ Attitude } \\
\hline Poor & 10 & 33.3 & 20 & 66.7 & 30 & 100.0 & \multirow{2}{*}{$\begin{array}{c}1.8 \\
(0.5-7.1)\end{array}$} & \\
\hline Good & 2 & 18.2 & 9 & 81.8 & 11 & 100.0 & & 0.577 \\
\hline \multicolumn{9}{|l|}{ Motivation } \\
\hline Low & 5 & 35.7 & 9 & 64.3 & 14 & 100.0 & \multirow{2}{*}{$\begin{array}{c}1.4 \\
(0.5-3.6)\end{array}$} & \\
\hline High & 7 & 25.9 & 20 & 74.1 & 27 & 100.0 & & 0.771 \\
\hline
\end{tabular}

$\mathrm{PR}=$ prevalence ratio

not comply. The prevalence ratio for hand hygiene practice based on level of knowledge was 12.7 (95\%CI: 1.8-89.8; $\mathrm{p}=0.001$ ), signifying nurses with low knowledge categories had 12.737 times greater chance to not comply with proper hand hygiene practices compared to those with high knowledge.

Based on attitude toward hand hygiene practices, a third (33.3\%) nurses with poor attitude did not comply with the proper hand hygiene, whilst $18.2 \%$ of those with good attitude did not comply either. The prevalence ratio was 1.8 with $95 \% \mathrm{CI}$ : $0.5-7.1$ and $\mathrm{p}=0.577$ which show that there is no statistically significant association between attitude and compliance with hand hygiene practices.

For the motivation to perform hand hygiene practices, we also found no statistically significant result $(\mathrm{p}=0.771)$ as shown in Table 3 . It can be seen that $35.7 \%$ nurses with low motivation did not comply with hand hygiene practices, while $25.9 \%$ of those with high motivation did not comply with the practices.

\section{DISCUSSION}

We found a significant relationship between knowledge and nurses' compliance with hand hygiene practices. Knowledge is a factor that can influence a person's behavior so that behavior which based on knowledge will last longer. ${ }^{11}$

Good knowledge is supported by the level of education, if someone has a high level of education in accordance with his/her competence, it will make them easier to embrace the information such as the nurses' awareness in performing hand hygiene. Level of education influences the reception of information. Education has an important role in determining human quality, thus nurses' high level of education should improve the quality of nursing care in hospitals. ${ }^{12}$

Based on our observations, most nurses who were not compliant in doing hand hygiene were those who had not received training on prevention and control of nosocomial infections provided by hospitals. This is supported by previous research which shows that knowledge is related to nurse hand hygiene compliance, and lack of knowledge is caused by lack of information and training provided by hospitals. ${ }^{13}$ Previous study shows that most nurses who adhere to the implementation of hand hygiene are mostly found in the group of nurses who have received infection control training. ${ }^{14}$ Knowledge enhancement can also be obtained through information from various media provided by hospitals related to compliance with hand hygiene practices, for instance through the printed media. ${ }^{15}$

The results of this study indicate no significant relationship between nurses' attitudes and compliance with hand hygiene practices. Good nurses' attitude will affect compliance with good hand hygiene ${ }^{16}$, but this study shows that there are still some nurses who did not comply to perform hand hygiene practices. A total of twelve nurses were often found did not do hand hygiene before having a contact with patients or performing clean/sterile procedures. Poor hand hygiene practices were also found when wearing gloves, nurses did not perform hand hygiene before using gloves. Gloves cannot replace the function of washing hands because of the possibility of small damage that is not visible to the eye. ${ }^{17}$

Attitude can help to achieve goals so that someone will have positive or negative behaviors. ${ }^{16}$ The attitude showed by some nurses does not always lead to good hand hygiene practice, which may be due to the high workload with a large number of 
patients. The workload of nurses is high that may make nurses were rush to take care of patients. ${ }^{18}$ Workload factors have an influence on compliance with hand hygiene, the higher the workload, the more likely the person to not comply with hand hygiene practices. ${ }^{19}$

We found no significant association between motivation and nurse's compliance with hand hygiene practices. This is probably due to the low level of awareness on proper hand hygiene. Motivation is not always able to increase morale in behavior because there are several intrinsic and extrinsic factors that influence one's motivation since the needs and desires of each person is different. $^{20}$

If nurses realize that implementing hand hygiene is important for every health worker, nurses will do hand hygiene properly and correctly. This indicates the need for self-awareness of the individual to do hand hygiene properly. Support from the head of the room or the chairperson can also increase compliance with hand hygiene behaviors. Coworkers are also one of the factors that can influence a person to take an action. Awareness in humans is a reflection of behavior, self-awareness is also formed based on experiences and environment so that awareness arises from oneself rather than coercion. This awareness will cause humans to make changes in their behavior. ${ }^{21}$

Nurses' motivation can be improved through the provision of rewards (awards) to nurses who have good compliance with the implementation of hand hygiene according to standards. So far, there has been no reward for nurses in this study hospital, but it has already been suggested by the management. In addition, training programs, seminars, workshops and provision of adequate compensation can positively increase nurses' motivation.

The study subject to some limitations. This study was conducted in only one inpatient room at one hospital and the sample size was small, therefore, interpretation and generalization of the results should be conducted carefully. Further study should involve bigger samples and conducted in several health facilities to have a better picture on compliance with hand hygiene practices among health professionals.

\section{CONCLUSION}

We found compliance to hand hygiene practice among nurses at Class III inpatient rooms at PKU Muhammadyah Gamping Hospital was $70.7 \%$. Variable related to the level of nurses' compliance with hand hygiene behavior is knowledge, while attitude and motivation were not significantly associated. It is necessary to increase knowledge through training on nurse compliance with the prevention and control of nosocomial infections, especially regarding procedure of proper hand hygiene practices. Rewards and punishments should be also considered by the management.

\section{ACKNOWLEDGMENTS}

We would like to thank all respondents who were willing to be participants in this study.

\section{AUTHOR CONTRIBUTION}

LS, GA and SMA designed the study, collected and analyzed the data, and wrote and edited the manuscript.

\section{CONFLICT OF INTEREST}

No conflicts of interest declared by the authors.

\section{REFERENCES}

1. Septiari BB. Infeksi Nosokomial. Yogyakarta: Nuha Medika, 2012.

2. World Health Organization. WHO Guidelines on Hand Hygiene in Health Care: First Global Patient Safety Challenge Clean Care is Safer Care. Geneva; 2009.

3. Ministry of Health of The Republic of Indonesia. Peraturan Menteri Kesehatan No. 27 Tahun 2017 tentang Pedoman Pencegahan dan Pengendalian Infeksi di Fasilitas Pelayanan Kesehatan [Regulation of the Indonesia Ministry of Health Number 27 Year 2017 regarding Guidelines for Infection Prevention and Control in Health Care Facilities]. Jakarta; 2017.

4. Voidazan S, Albu S, Toth R, Grigorescu B, Rachita A, Moldovan I. Healthcare associated infections-a new pathology in medical practice. Int. J. Environ. Res. Public Health. 2020; 17(3):1-13.

5. Zhang Y, Zhong ZF, Chen SX, Zhou DR, Li ZK, Meng Y, et al. Prevalence of healthcare-associated infections and antimicrobial use in China: Results from the 2018 point prevalence survey in 189 hospitals in Guangdong Province. Int. J. Infect. Dis. 2019; 89:179-184.

6. Dewi RRK. Faktor determinan kepatuhan perawat dalam melakukan praktik cuci tangan di RSUD Ade Muhammad Djoen Sintang [Determinants of nurses' compliance with hand hygiene practice at Ade Muhammad Djoen Hospital, Sintang]. J. Kesmas (Kesehatan Masyarakat) Khatulistiwa. 2017;4(3):232.

7. Ratnasari D, Dulakhir. Faktor-faktor yang berhubungan dengan kepatuhan perawat ruang rawat inap dalam pelaksanaan hand hygiene di Rumah Sakit Anna Medika Kota Bekasi [Factors associated with inpatient room nurses' compliance in hand hygiene practice at Anna Medika Hospital, Bekasi City]. Jurnal Ilmiah Kesehatan. 2016;8(2):30-34.

8. Ratnawati L, Sianturi S. Faktor-faktor yang berhubungan dengan kepatuhan perawat dalam menerapkan hand hygiene [Factors associated with nurses' compliance in hand hygiene practice]. J. Ilmu Keperawatan dan Kebidanan. 2018;9(2):148-154.

9. Soedarto. Infeksi nosokomial di rumah sakit [Nosocomial infections in hospitals]. Yogyakarta: Sagung Seto, 2016.

10. Purnawati E, Junaiddin, Mewanglo. Faktor yang berhubungan dengan kepatuhan perawat dalam melakukan 
hand hygiene five moment di Ruang Rawat RSUD Labuang Baji Makassar [Factors associated with nurses' compliance in five moment hand hygiene at inpatient rooms Labuang Baji District Hospital, Makassar]. Jurnal Ilm. Kesehat. Diagnosis. 2018;12(1):14-19.

11. Notoatmodjo S. Promosi kesehatan dan perilaku kesehatan [Health promotion and health behavior]. Jakarta: Rineka Cipta, 2012.

12. Handojo L. Pengetahuan perawat tentang infeksi nosokomial di Ruang D2 dan D3 Rumah Sakit Adi Husada Undaan Wetan Surabaya [Knowledge of nurses on nosocomial infections at D2 and D3 Rooms, Adi Husada Undaan Wetan Hospital, Surabaya]. Adi Husada Nurs. 2015;1(1):1-5.

13. Gea IAY, Fitriani AD, Theo D. Faktor kepatuhan perawat dalam penerapan hand hygiene di Instalasi Rawat Inap RSUD Gunung Sitoli [Factors of nurses' compliance in hand hygiene practice at the Inpatient Wards, Gunung Sitoli District Hospital]. J. Kesehat. Glob. 2018;1(3):102109.

14. Amalia R, Widagdo L, Syamsulhuda BM. Faktor-faktor yang berhubungan dengan tingkat kepatuhan tenaga kesehatan melakukan cuci tangan (Studi kasus di Instalasi Rawat Inap Rajawali RSUP Dr. Kariadi Semarang) [Factors associated with compliance of health providers in hand hygiene practice (Case study at Rajawali Inpatient Wards, Dr. Kariadi Hospital Semarang]. J. Kesehat. Masy. 2016;4(3): 1083-1088.

15. Canti PR, Husodo BT, Mustofa SB. Hubungan paparan media informasi terhadap praktik hand hygiene pada penunggu pasien di Instalasi Rawat Inap RSUD Dr. Adhyatma Tugurejo Kota Semarang [Association between information media exposures towards hand hygiene practice among those accompanying patients at the Inpatient Wards Dr. Adhyatma Tugurejo Hospital, Semarang]. J. Kesehat. Masy. 2016; 4(5): 370-378.
16. Manahulending N, Tandipajung T. Hubungan pengetahuan dan sikap perawat dengan kepatuhan mencuci tangan pada tindakan pemasangan infus di Ruang Rawat Inap Puskesmas Lirung [The association between knowledge and attitudes of nurses with hand hygiene compliance in preparing infusion at inpatient room Lirung Public Health Center]. Bul. Sariputra. 2015;5(3):7-14.

17. Setio H, Rohani. Panduan praktik keperawatan infeksi nosokomial [Guidelines on nosocomial infections care practices]. Yogyakarta: Citra Aji Parama, 2010.

18. Nurani RS, Hidajah AC. Gambaran kepatuhan hand hygiene pada perawat hemodialisis di Rumah Sakit Umum Haji Surabaya [Hand hygiene compliance among hemodialisis nurses at Haji General Hospital Surabaya]. J. Berk. Epidemiol. 2017;5(2): 218-230.

19. Fauzia N, Rahmawati. Pengaruh faktor individu terhadap kepatuhan perawat dalam melaksanakan hand hygiene [The influence of individual factors towards nurses' compliance in hand hygiene practices]. J. Ilmu Keperawatan. 2018; 6(1): $40-46$.

20. Tahir N. Motivasi kerja pegawai dalam pelayanan publik di Sekretariat Pemerintah Daerah Kabupaten Takalar [Work motivation of public services staff at Takalar District Local Government Secretariat]. J. Ad'ministrare. 2016;3(2).

21. Uswatusolihah U. Kesadaran dan transformasi diri dalam kajian dakwah Islam dan komunikasi [Awareness and self transformation in an Islamic study and coomunication]. KOMUNIKA J. Dakwah dan Komun. 2017;9(2): 257-275.

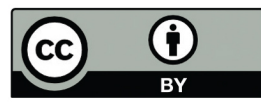

This work is licensed under a Creative Commons Attribution 